\title{
Regional Patterns in the Quality of Bank Assets
}

\section{R. Alton Gilbert}

$\mathrm{T}$ he quality of U.S. bank assets varied during the late 1980 s and early 1990s. At various times during this period the average asset quality of banks in New England, the Southwest, and California was unusually poor relative to that of banks in other parts of the nation. Since the asset quality problems of banks in these three regions peaked at different times, differences in measures of asset quality across regions remained large for an extended period. I compare the recent range of differences in asset quality across regions (during the recent recession and current economic expansion) with comparable data for the late 1980s and early 1990s.

The measure of asset quality shown here is the percentage of commercial and industrial (C\&I) loans that are nonperforming (past due $\geq 90$ days or classified as nonaccrual). This measure of asset quality for community banks (often identified as banks with total assets less than $\$ 1$ billion) is more likely to reflect the economic conditions in the Census divisions of their headquarters than would the nonperforming loan ratios of very large banks with offices located in several regions. In the top chart the shaded area is the range of the average nonperforming C\&I loan ratios for relatively small community banks (total assets $<\$ 300$ million) across the nine Census divisions (groups of contiguous states) since 1988; the solid line is the average nonperforming C\&I loan ratio for these relatively small community banks. The decline in this line indicates that the average nonperforming loan ratio at these banks was higher during the late 1980s and early 1990s than during the recent recession and current economic expansion. The range of the average nonperforming C\&I loan ratio across the Census divisions shrank substantially during the second half of the 1990s and did not widen during the recession of 2001 or the following economic expansion. The patterns are similar for the nonperforming C\&I loan rate for banks with total assets between $\$ 300$ million and $\$ 1$ billion and for the nonperforming rate on total loans for community banks in each of the two size groups (above and below $\$ 300$ million, not shown). Regional differences in asset quality have been very small during recent quarters relative to the size of the differences in the late 1980s and early 1990s. ${ }^{1}$

Differences in the pace of economic activity across regions of the nation began declining during the 1990s, which may explain the narrowing of the range of bank asset quality across regions since the mid-1990s. The bottom chart shows the range of growth rates of nonfarm employment across the nine Census divisions; the solid line is the national growth rate of employment, and the shaded area is the range of growth rates across Census divisions. The range of the growth rates of employment narrowed substantially around 1997. The average range of growth rates across Census divisions was 4.5 percentage points for 1988-96, compared with 2 percentage points for 1997-2002. ${ }^{1}$ Measures of bank performance each quarter by bank size and Census division
are available from this Bank at http://research.stlouisfed.org/fred2/categories/83.

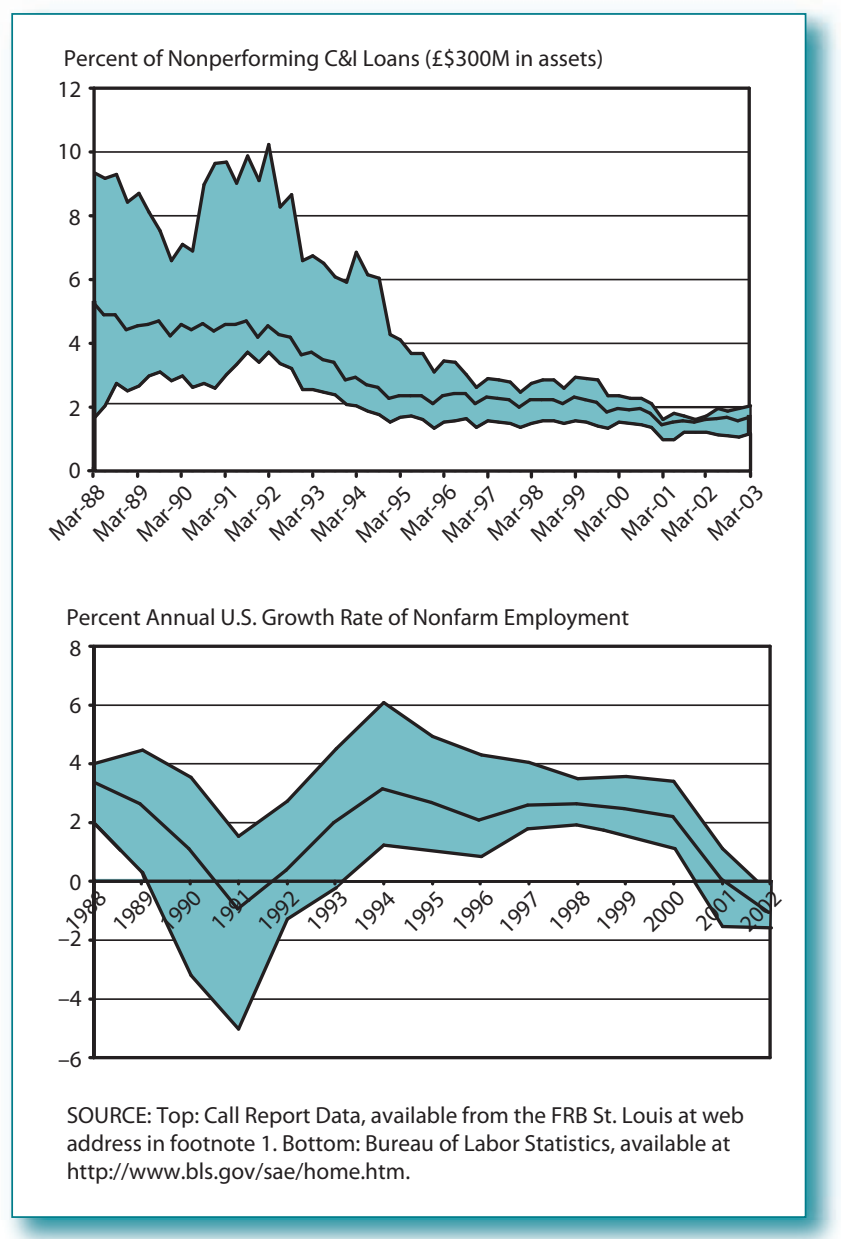

